This work is licensed under Creative Commons Attribution 4.0 International (CC BY 4.0). [http://creativecommons.org/licenses/by/4.0/]

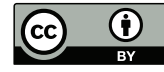

\title{
Problem uzasadnienia wypowiedzenia umowy o pracę przez pracodawcę
}

Eugenia Tereszczenko | Uniwersytet Gdański https://orcid.org/0000-0002-3423-9357

Słowa kluczowe:

umowa o pracę, wypowiedzenie, uzasadnienie, pracodawca

employment

contract

termination

justification,

employer

\section{Streszczenie}

Wypowiedzenie umowy o pracę jest jednym ze sposobów ustania stosunku pracy, który przewiduje Kodeks pracy. Zgodnie z jego art. 30 § 4 w oświadczeniu pracodawcy o wypowiedzeniu umowy o pracę zawartej na czas nieokreślony lub o rozwiązaniu umowy o pracę bez wypowiedzenia powinna być wskazana przyczyna uzasadniająca wypowiedzenie lub rozwiązanie umowy.

Wskazanie w oświadczeniu o wypowiedzeniu umowy o pracę przyczyny pozornej, nieprawdziwej będzie równoznaczne z brakiem wskazania przyczyny uzasadniającej wypowiedzenie. Kryteriów oceny zasadności wypowiedzenia umowy o pracę należy szukać w regulacjach pozakodeksowych, dlatego ocena zasadności każdego konkretnego wypowiedzenia będzie nosiła indywidualny charakter.

Regulacje dotyczące ograniczenia prawa wypowiedzenia umowy o pracę przez pracodawcę znajdują się nie tylko w systemie polskiego prawa pracy, lecz również w aktach prawa unijnego.

\section{Employer's justification of employment contract termination (Summary)}

Termination of employment contract is one of the ways of ending employment, that is contained in Labour Code. According to the article of $30 \S 4$ of the Labour Code every termination must have a reason, indicated by employer with declaration of will.

Indication of ostensible or untrue reasons in the declaration of termination of the employment contract lack of indication of the reason justifying the termination. Criteria for assessing the validity of terminating a contract of employment should be sought in non-code regulations. Therefore, the assessment of the merits of each specific notice will be individual.

Regulations concerning the limitation of the right to terminate an employment contract by an employer exist not only in the system of Polish labor law, but also in the acts of international law. 


\section{Wstęp}

Wypowiedzenie umowy o pracę jest jedną z podstawowych instytucji prawa pracy, która odgrywa doniosłą rolę w stosunkach pomiędzy pracodawcą a pracownikiem. Jest ono jednym ze sposobów ustania stosunku pracy, który przewiduje ustawa z dnia 26 czerwca 1974 r. Kodeks pracy (t.j. Dz. U. z 2018 r., poz. 907) (dalej: KP). Naruszenie tych przepisów skutkuje powstaniem po stronie pracownika całego szeregu roszczeń w zależności od danej sytuacji.

Obowiązek uzasadnienia wypowiedzenia umowy o pracę został nałożony na pracodawcę przepisami Kodeksu pracy, który wszedł w życie 1 stycznia 1975 r. Wynika on z klauzuli generalnej „przyczyn uzasadniających wypowiedzenie” i klauzuli „nie-

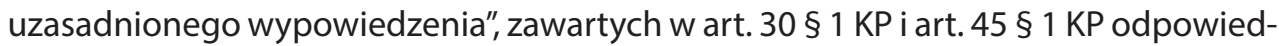
nio (Rycak 2018: 174). Obowiązek ten jest przejawem instytucji powszechnej ochrony trwałości stosunku pracy (Rycak 2018: 174). Poprzez wprowadzenie danego wymogu do Kodeksu pracy ustawodawca ogranicza podmiotowe prawo pracodawcy do rozwiązania umowy o pracę wynikające z zasady swobody umów.

Regulacja dotycząca ograniczenia prawa wypowiedzenia umowy o pracę przez pracodawcę do sytuacji, w których istnieją ważne przyczyny takiego wypowiedzenia, znajduje się nie tylko w systemie polskiego prawa pracy. Tak np. art. 4 Konwencji Międzynarodowej Organizacji Pracy Nr 158 (MOP 2019) stanowi, iż stosunek pracy z pracownikiem nie będzie rozwiązany, jeżeli nie istnieje ważna przyczyna takiego rozwiązania, wiążąca się z umiejętnościami lub zachowaniem się pracownika albo uzasadniona wymogami funkcjonowania przedsiębiorstwa, zakładu lub działu. Podobny przepis zawarto w Zrewidowanej Europejskiej Karcie Społecznej (2016), w której art. 24 znajduje się prawo pracowników do niebycia zwolnionymi bez uzasadnionego powodu związanego z ich predyspozycjami lub zachowaniem, lub opartego na konieczności związanej z działalnością przedsiębiorstwa, zakładu lub służby. Obydwa te akty prawne obecnie nie są ratyfikowane przez Polskę.

Celem artykułu jest przedstawienie problemu uzasadnienia wypowiedzenia umowy o pracę w przypadku umowy o pracę zawartej na czas nieokreślony w świetle poglądów doktryny i orzecznictwa.

\section{Wypowiedzenie umowy o pracę jako jeden ze sposobów ustania stosunku pracy}

Ustanie stosunku pracy może nastąpić zarówno w drodze rozwiązania umowy o pracę na skutek czynności prawnych (jednostronnych czy dwustronnych) lub upływu czasu, jak i w wyniku różnych zdarzeń prawnych, które doprowadzą do wygaśnięcia tego stosunku. Niektóre z tych zdarzeń są uregulowane w rozdziale II działu drugiego Kodeksu pracy, inne zaś znalazły swoje uregulowanie w układach zbiorowych pracy lub w pragmatykach regulujących prawa i obowiązki pracowników sektora publicznego (Rycak 2018: 151). 
Na gruncie polskiego prawa pracy do zdarzeń, które skutkują wygaśnięciem stosunku pracy, przyjęto zaliczać następujące przypadki:

1) śmierć pracownika (art. $63^{1} \S 1 \mathrm{KP}$ );

2) śmierć pracodawcy, jeżeli jest to osoba fizyczna, chyba że dochodzi do przejścia zakładu pracy na innego pracodawcę (art. 63² KP);

3) z upływem 3 miesięcy nieobecności pracownika w pracy z powodu tymczasowego aresztowania, chyba że pracodawca rozwiązał wcześniej bez wypowiedzenia umowę o pracę z winy pracownika (art. $66 \S 1 \mathrm{KP}$ );

4) niezgłoszenie pracownika w ciągu trzydziestu dni od dnia zwolnienia ze służby do zakładu pracy w celu podjęcia pracy w tym zakładzie, chyba że nastąpiło z przyczyn usprawiedliwiających nieobecność w pracy (art. 122 ustawy o powszechnym obowiązku obrony Rzeczypospolitej Polskiej, Dz. U. z 2019 r., poz. 55);

5) w razie niezgłoszenia przez pracownika w ciągu 7 dni od rozwiązania stosunku pracy z wyboru (art. 74KP) swojego powrotu do pracy.

Oprócz przypadków wymienionych wyżej niektóre pragmatyki służbowe przewidują własne przyczyny wygaśnięcia stosunku pracy. Takim przykładem może być wygaśnięcie umowy o pracę na skutek prawomocnego orzeczenia kary dyscyplinarnej wydalenia ze służby urzędnika służby cywilnej (Rycak 2018: 230).

W art. 30 § $1 \mathrm{KP}$ są wymienione następujące możliwości rozwiązania umowy o pracę na skutek złożenia oświadczenia woli przez strony lub upływu czasu:

1) na mocy porozumienia stron;

2) przez oświadczenie jednej ze stron z zachowaniem okresu wypowiedzenia (rozwiązanie umowy o pracę za wypowiedzeniem);

3) przez oświadczenie jednej ze stron bez zachowania okresu wypowiedzenia (rozwiązanie umowy o pracę bez wypowiedzenia);

4) z upływem czasu, na który była zawarta.

W stosunku do umowy o pracę na czas próbny art. 30 § $2 \mathrm{KP}$ dodatkowo zawiera regulację, zgodnie z którą taka umowa rozwiązuje się z upływem okresu próbnego, a przed jego upływem może być rozwiązana za wypowiedzeniem.

Praktyka wskazuje, że rozwiązanie umowy o pracę za wypowiedzeniem jest jednym z najczęściej stosowanych sposobów ustania stosunku pracy, w przypadku gdy umowa była zawarta na czas nieokreślony.

\section{Wymogi dotyczące wypowiedzenia umowy o pracę przez pracodawcę}

Na podstawie art. 30 § 1 KP możemy wywnioskować, że wypowiedzenie umowy o pracę jest jednostronną czynnością prawną, która skutkuje rozwiązaniem stosunku pracy. Rozwiązanie to następuje z upływem ostatniego dnia okresu wypowiedzenia, czyli terminu, który jest czasem pomiędzy dniem skutecznego złożenia oświadczenia woli przez jedną ze stron a dniem, w którym stosunek pracy rozwiązuje się (Rycak 2018: 
171). Przy czym skuteczność oświadczenia woli będzie oceniana według art. 61 ustawy z dnia 23 kwietnia 1964 r. Kodeks cywilny (t.j. Dz. U. z 2018 r., poz. 1025).

Kodeks pracy przewiduje różne okresy wypowiedzenia w zależności od rodzaju umowy o pracę oraz stażu pracy pracownika, które mogą być liczone w dniach, tygodniach oraz miesiącach. W doktrynie przyjmuje się, że informacja o okresie i terminie wypowiedzenia powinna znajdować się w treści wypowiedzenia umowy o pracę (Rycak 2018: 170).

Dla skuteczności jednostronnej czynności prawnej wystarczy, żeby jedna ze stron stosunku prawnego, w tym i stosunku pracy, złożyła oświadczenie woli. Ze złożeniem danego oświadczenia woli w art. 30 § 3 KP ustawodawca powiązał wymóg zachowania formy pisemnej, niezachowanie którego przez pracodawcę skutkuje określonymi w Kodeksie pracy konsekwencjami. Niezachowanie formy pisemnej w tym przypadku będzie stanowiło naruszenie przepisów prawa o wypowiedzeniu umów o pracę,

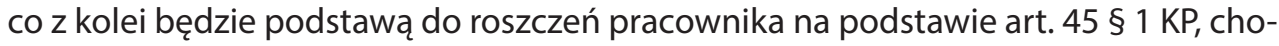
ciaż samo wypowiedzenie przy niezachowaniu formy pisemnej będzie skuteczne.

Nie budzi wątpliwości, że celem takiego uregulowania jest ochrona pewności obrotu prawnego co do istnienia lub nieistnienia stosunku pracy.

Należy podkreślić, iż forma pisemna na gruncie prawa pracy jest rozumiana tak samo jak i na gruncie prawa cywilnego. W związku z tym przyjmuje się, że wypowiedzenie musi być sporządzone na dokumencie zaopatrzonym własnoręcznym podpisem. Wypowiedzenie przesłane za pomocą faksu, przez telefon (SMS) lub pocztą elektroniczną nie będzie spełniało wymogu formy pisemnej (Rycak 2018: 161). Tymczasem warto zwrócić uwagę, iż doręczenie pracownikowi za pomocą faksu pisma pracodawcy wypowiadającego umowie o pracę jest skuteczne i powoduje rozpoczęcie terminu przewidzianego $\mathrm{w}$ art. 264 § $1 \mathrm{KP}$ dla możliwości odwołania do sądu przez pracownika, ale stanowi naruszenie art. 30 § 3 KP (uchwała SN z 02.10.2002, III PZP 17/2002).

Przytoczenie pouczenia o przysługującym pracownikowi prawie odwołania do sądu pracy jest z kolei następującym wymogiem dotyczącym treści wypowiedzenia umowy o pracę przez pracodawcę. Regulacja ta jest zawarta w art. $30 \S 5$ KP. Nieprzytoczenie takiego pouczenia o prawie odwołania się od wypowiedzenia oraz o terminie dokonania tej czynności może stanowić okoliczność usprawiedliwiającą przekroczenie tego terminu (wyrok SN z 23.11.2000, I PKN 117/00).

Zgodnie z art. 30 § 4 KP w oświadczeniu pracodawcy o wypowiedzeniu umowy o pracę zawartej na czas nieokreślony lub o rozwiązaniu umowy o pracę bez wypowiedzenia powinna być wskazana przyczyna uzasadniająca wypowiedzenie lub rozwiązanie umowy. Regulacja zawarta w art. 30 § KP jest przejawem wymogu formalnego wskazania przyczyny uzasadniającej wypowiedzenie umowy o pracę, a nie jej rzeczywistego występowania i oceny, czy jest to przyczyna faktycznie uzasadniająca wypowiedzenie (wyrok SN z 24.03.1999, I PKN 637/98). W ramach spełnienia wymogów danego artykułu pracodawca może podać przyczynę wypowiedzenia, lecz nie będzie to przyczyna dostateczna w rozumieniu art. $45 \S 1 \mathrm{KP}$. Brak przyczyny uzasadniającej 
wypowiedzenie umowy o pracę skutkuje też powstaniem roszczeń z art. $45 \S 1 \mathrm{KP}$, choćby pracodawca nie naruszał wymogu z art. 30 § KP (wyrok SN z 15.04.1999, I PKN 9/99). Wskazanie w oświadczeniu o wypowiedzeniu umowy o pracę przyczyny pozornej, nieprawdziwej będzie równoznaczne z brakiem wskazania przyczyny uzasadniającej wypowiedzenie (wyrok SN z 13.11.1999, I PKN 304/99).

Warto podkreślić, że ocena zasadności wypowiedzenia umowy o pracę zgodnie ze stanowiskiem Sądu Najwyższego powinna być dokonana przez sąd w granicach przyczyn podanych pracownikowi przez pracodawcę (wyrok SN z 10.11.1998, I PKN 434/98).

Podanie przez pracodawcę przyczyny uzasadniającej wypowiedzenie umowy o pracę może nastąpić w odrębnym piśmie doręczonym pracownikowi wcześniej lub równocześnie z pismem zawierającym wypowiedzenie umowy (wyrok SN z 17.11.1998, I PKN 331/98).

Oprócz wyżej wymienionych warunków, które muszą być spełnione przez pracodawcę, żeby wypowiedzenie było prawidłowe, istnieje jeszcze jeden wymóg zawarty W art. 38 § 1 KP. Wymóg ten dotyczy zawiadomienia na piśmie o zamiarze wypowiedzenia pracownikowi umowy o pracę zawartej na czas nieokreślony zakładowej organizacji związkowej reprezentującej pracownika, z podaniem przyczyny uzasadniającej rozwiązanie umowy. Obowiązek ten ciąży na pracodawcy tylko wtedy, gdy działa u niego związek zawodowy, nie ma natomiast zastosowania, jeżeli pracownicy należą do ponadzakładowej struktury związkowej (Florek 2011:225). Jak wynika z brzmienia tego przepisu, naruszeniem będzie nie tylko zawiadomienie organizacji związkowej po złożeniu wypowiedzenia pracownikowi, lecz jednoczesność tych dwóch czynności nie wchodzi w grę. Domniemywa się, że przyczyny, które będą wskazane w takim zawiadomieniu do zakładowej organizacji związkowej, następnie będą powtórzone bezpośrednio $w$ treści wypowiedzenia umowy o pracę.

\section{Zasadność wypowiedzenia umowy o pracę w świetle art. 45 § 1 KP — poglądy doktryny}

W doktrynie polskiego prawa wyróżnia się trzy modele konstrukcji prawnej przesłanek dopuszczalności wypowiedzenia. Według Artura Rycaka (2018: 175) pierwszy z tych modeli polega na obowiązywaniu ogólnego zakazu rozwiązania przez pracodawcę umowy o pracę za wypowiedzeniem bez uzasadnionych przyczyn. Zakaz ten jest wyrażony poprzez wprowadzenie klauzuli generalnej nieuzasadnionego wypowiedzenia do systemu prawnego.

Taki model miał miejsce w polskim prawie pracy dopóki w latach 2002-2004 nie był zmodyfikowany poprzez umiejscowienie w Kodeksie pracy negatywnych przesłanek, które na pewno nie mogą stanowić przyczyny wypowiedzenia umowy o pracę przez pracodawcę. Zgodnie z tymi wprowadzonymi do Kodeksu pracy przepisami przyczyną wypowiedzenia nie może być: 
1) przejście zakładu pracy lub jego części na innego pracodawcę (art. $23^{1} \S 6 \mathrm{KP}$ );

2) brak zgody pracownika na zmianę warunków wykonywania pracy w formie telepracy, a także zaprzestanie wykonywania pracy w formie telepracy (art. $67^{9} \mathrm{KP}$ );

3) skorzystanie przez pracownika z uprawnień przysługujących z tytułu naruszenia zasady równego traktowania w zatrudnieniu (art. $18^{3 \mathrm{e}} \S 1 \mathrm{KP}$ );

4) wsparcie pracownikowi korzystającemu z uprawnień przysługujących z tytułu naruszenia zasady równego traktowania w zatrudnieniu (art. $18^{3 e} \S 2 \mathrm{KP}$ ).

Drugi i trzeci model konstrukcji prawnej przesłanek dopuszczalności wypowiedzenia według Rycaka polega na wskazaniu w pierwszym przypadku przesłanek pozytywnych, które mogą być podstawą wypowiedzenia umowy o pracę, lecz w drugim przypadku a contrario na wskazaniu przesłanek negatywnych (Rycak 2018: 175).

Klauzula generalna nieuzasadnionego wypowiedzenia w polskim prawie pracy zawarta została w art. 45 § 1 KP. Ten artykuł nie zawiera katalogu przyczyn pozytywnych, które stanowiłyby podstawę dla wypowiedzenia umowy o pracę przez pracodawcę. Nie ma takich przyczyn i w pozostałych przepisach Kodeksu pracy. Wynika z tego, iż kryteriów oceny zasadności wypowiedzenia umowy należy szukać w regulacjach pozakodeksowych (Florek 2011: 323). W związku z czym ocena zasadności każdego konkretnego wypowiedzenia będzie nosiła indywidualny charakter.

Oczywisty jest fakt, że korzystanie przez ustawodawcę z klauzuli generalnych uelastycznia prawo, pomaga uniknąć kazuistyki i doprowadzić do skutecznego rozstrzygnięcia większej ilości spraw bez zbędnego rozbudowania aktów prawnych. Z drugiej strony sprzyja to zaistnieniu rozbieżności interpretacyjnych oraz niejasności i dowolności w stosowaniu prawa (Florek 2011: 323).

Wszystkie przyczyny uzasadniające wypowiedzenie umowy o pracę Ludwik Florek w komentarzu do art. 45 § 1 KP proponuje dzielić na dwie zasadnicze grupy (Florek 2011: 324):

1) przyczyny występujące po stronie pracownika;

2) przyczyny występujące po stronie pracodawcy.

Pierwsza grupa z kolei może być podzielona dodatkowo na przyczyny związane z nagannym postępowaniem pracownika (z wyjątkiem przyczyn, które uzasadniają zwolnienie pracownika bez wypowiedzenia w trybie dyscyplinarnym) oraz na przyczyny spowodowane całkowitą lub częściową nieprzydatnością pracownika do wykonania pracy określonego rodzaju (Florek 2011: 324). Z tą drugą kategorią wiążą się przypadki niezdolności pracownika na skutek szczególnego stanu zdrowia lub niezawinionej przez pracownika utraty uprawnień do wykonywania określonej pracy (Florek 2011: 324).

Przyczyny występujące po stronie pracodawcy najczęściej są tymi, które zostały przewidziane dla ustawy z dnia 13 marca 2003 r. o szczególnych zasadach rozwiązywania z pracownikami stosunków pracy z przyczyn niedotyczących pracowników (t.j. Dz. U. z 2018 r., poz. 1969). Mogą nimi być przykładowo takie zdarzenia, jak: kryzys gospodarczy, upadłość przedsiębiorstwa pracodawcy czy zmiany organizacyjne. 
Dla oceny zasadności wypowiedzenia umowy o pracę przez pracodawcę może być przydatny art. $100 \mathrm{KP}$ wymieniający ogólne obowiązki pracownika. W szczególności na pracownikach spoczywają następujące obowiązki:

1) wykonywać pracę sumiennie i starannie oraz stosować się do poleceń przełożonych, które dotyczą pracy, jeżeli nie są one sprzeczne z przepisami prawa lub umową o pracę;

2) przestrzegać czasu pracy ustalonego w zakładzie pracy;

3) przestrzegać regulaminu pracy i ustalonego w zakładzie pracy porządku;

4) przestrzegać przepisów oraz zasad bezpieczeństwa i higieny pracy, a także przepisów przeciwpożarowych;

5) dbać o dobro zakładu pracy, chronić jego mienie oraz zachować $w$ tajemnicy informacje, których ujawnienie mogłoby narazić pracodawcę na szkodę;

6) przestrzegać tajemnicy określonej w odrębnych przepisach;

7) przestrzegać w zakładzie pracy zasad współżycia społecznego.

Przykładem pokazującym, iż te przyczyny faktycznie stanowią podstawę uzasadniającą wypowiedzenie umowy o pracę będzie wyrok Sadu Najwyższego z dnia 28 kwietnia 1997 r. (I PKN 118/97). Ten wyrok stanowi, że „popieranie przez pracownika szkodzących pracodawcy działań zmierzających do ogłoszenia jego upadłości, a zwłaszcza przejęcia maszyn i urządzeń przez spółkę, w której pracownik jest udziałowcem, stanowi naruszenie obowiązku dbałości o dobro pracodawcy (art. 100 § 2 pkt 5 KP) i uzasadnia wypowiedzenie umowy o pracę na czas nieokreślony".

\section{Zasadność wypowiedzenia umowy o pracę w świetle art. 45 § 1 KP - przegląd orzecznictwa}

Jak często bywa w przypadkach zastosowania przez ustawodawcę klauzuli generalnej, dla oceny i interpretacji konkretnej sytuacji lub zdarzenia należy zwrócić się do praktyki sądowej i rozpatrzenia konkretnych spraw. Orzecznictwo Sądu Najwyższego na temat uzasadnienia wypowiedzenia umowy o pracę jest dosyć rozbudowane, co pokazuje aktualność problemu. Ogół wypowiedzi Sądu Najwyższego można podzielić na dwa zasadnicze kierunki: orzeczenia, w których Sąd Najwyższy formułuje ogólne zasady oceny zasadności wypowiedzenia, oraz orzeczenia, w których dokonuje się ocena konkretnej sytuacji (Florek 2011: 324).

Przykładem orzeczenia, w którym Sąd Najwyższy formułuje ogólne zasady co do zasadności wypowiedzenia umowy o pracę, może posłużyć wyrok Sądu Najwyższego z dnia 4 grudnia 1997 r. (I PKN 419/97). Zgodnie z treścią uzasadnienia danego wyroku przyczyna wypowiedzenia umowy o pracę musi być konkretna i rzeczywista. Sąd Najwyższy w tym wyroku podkreśla, iż „przyczyna ta nie musi jednak mieć szczególnej wagi czy nadzwyczajnej doniosłości, skoro wypowiedzenie jest zwykłym sposobem rozwiązania bezterminowego stosunku pracy" (wyrok SN z 04.12.1997, I PKN 419/97). Według stanowiska Sądu Najwyższego „brak oczekiwanej przez pracodawcę dbałości, 
staranności i uwagi w wykonywaniu obowiązków pracowniczych uzasadnia wypowiedzenie pracownikowi umowy o pracę" (wyrok SN z 04.12.1997, I PKN 419/97).

Wyrokiem potwierdzającym stanowisko oznaczone w wyroku poprzednim, zgodnie z którym rozwiązanie umowy o pracę za wypowiedzeniem jest zwykłym sposobem rozwiązania stosunku pracy i zasadność jej wypowiedzenia należy oceniać, biorąc pod uwagę taki pogląd, jest wyrok Sądu Najwyższego z dnia 2 października $1996 \mathrm{r}$. (I PKN 69/96). W związku z tym „pracodawca w sposób zasadny wypowiada umowę o pracę pracownikowi samodzielnie organizującemu wykonywanie swoich obowiązków pracowniczych, jeżeli pracownik ten nie osiąga wyników porównywalnych z innymi pracownikami" (wyrok SN z 02.10.1996, I PKN 69/96). Sąd Najwyższy doprecyzuje, iż w tej sytuacji „obojętne jest czy spowodowane to zostało niestarannym wykonywaniem obowiązków przez pracownika czy przyczynami obiektywnymi, leżącymi po stronie pracownika” (wyrok SN z 02.10.1996, I PKN 69/96). .,Pracodawca może zasadnie wypowiedzieć umowę o pracę w ramach realizacji zasady doboru pracowników w sposób zapewniający najlepsze wykonywanie realizowanych zadań, jeżeli może przewidywać, że zatrudnienie nowych pracowników pozwoli na osiąganie lepszych rezultatów pracy" (wyrok SN z 02.10.1996, I PKN 69/96). Wyrażone w danym wyroku stanowisko odpowiada zasadzie, że przy ocenie zasadności wypowiedzenia umowy o pracę należy uwzględnić słuszny interes zakładu pracy.

Na poparcie stwierdzenia, iż rozwiązanie umowy o pracę za wypowiedzeniem jest normalnym sposobem rozwiązania umowy o pracę zawartej na czas nieokreślony można przytoczyć wyrok Sądu Najwyższego z dnia 4 kwietnia 1979 r. (I PKN 32/79). Oprócz powtórzenia poprzedniej tezy $w$ tym wyroku zwrócono uwagę, iż przy wypowiedzeniu umowy o pracę nie musi być stwierdzona wina pracownika, lecz tylko musi być wskazane uzasadnienie rozwiązania stosunku pracy w takim trybie.

Wyrok Sądu Najwyższego z dnia 18 kwietnia 2001 r. (I PKN 370/00) stwierdza, iż „przyczyny wypowiedzenia nie muszą charakteryzować się znaczną wagą ani powodować szkód po stronie pracodawcy". Przyczyną uzasadnienia wypowiedzenia nie musi być zawinione działanie pracownika.

Zasadą, która wykształciła się na tle orzeczeń sądów okręgowych razem z Sądem Najwyższym, będzie reguła, zgodnie z którą zasadne będzie wypowiedzenie umowy o pracę pracownikowi na stanowisku samodzielnym, jeżeli za tym przemawia konieczność wykonania zadań (Florek 2011: 325).

Kolejnym przykładem utrwalonego w orzecznictwie poglądu będzie stwierdzenie, iż zasadność wypowiedzenia umowy o pracę na czas nieokreślony należy oceniać z uwzględnieniem łącznie wszystkich przyczyn wskazanych przez pracodawcę (wyrok SN z 08.01.2007, I PK 187/06).

Mówiąc o zasadach, zgodnie z którymi Sąd Najwyższy udziela wykładni art. $45 \S 1$ KP, należy zwrócić się do wytycznych Sądu Najwyższego z 1985 r. w sprawie stosowania art. 45 KP (uchwała SN z 27.06.1985 r.). 
Jak wskazano w uzasadnieniu wytycznych tezy I, ze względu na zawarcie w art. $45 \S 1 \mathrm{KP}$ zwrotu niedookreślonego, a mianowicie klauzuli generalnej „wypowiedzenia nieuzasadnionego", „nie jest możliwe wyczerpujące skatalogowanie przyczyn wypowiedzenia umowy o pracę ani ustalenie sztywnych kryteriów oceny wypowiedzenia, a tylko wskazanie głównych kierunków". W odpowiedzi na takie wyzwanie Sąd Najwyższy postarał się sformułować postulaty, o które należy opierać przyszłe rozstrzygnięcia dotyczące sporów na tle wypowiedzenia umowy o pracę przez pracodawcę. Podstawowe tezy, które wynikają z tej uchwały według Rycaka, są następujące: „1) przyczyna wypowiedzenia powinna być prawdziwa i konkretna;

2) ocena zasadności wypowiedzenia umowy o pracę w ramach art. 45 KP powinna być dokonana z uwzględnieniem słusznych interesów zakładu pracy oraz przymiotów pracownika związanych ze stosunkiem pracy. Inne okoliczności dotyczące pracownika, niezwiązane ze stosunkiem pracy, mogą w wyjątkowych wypadkach stanowić podstawę uznania na zasadzie art. $8 \mathrm{KP}$, że wypowiedzenie jest sprzeczne z zasadami współżycia społecznego;

3) okoliczności przemawiające za ochroną pracownika przed wypowiedzeniem uwzględnia się w stosunku do pracowników sumiennie i starannie wykonujących obowiązki pracownicze i przestrzegających dyscypliny pracy;

4) dla uznania zasadności wypowiedzenia decydujące znaczenie mają rodzaj i ciężar gatunkowy przyczyny wypowiedzenia. Waga tej przyczyny może przesądzać o bezskuteczności powoływania się pracownika na okoliczności dotyczące jego interesu;

5) w stosunku do pracowników na stanowiskach kierowniczych i samodzielnych należy stosować ostrzejsze kryteria oceny przyczyn uzasadniających wypowiedzenie;

6) nienależyte wykonywanie obowiązków pracowniczych stanowi uzasadnioną przyczynę wypowiedzenia nie tylko wtedy, gdy jest zawinione, lecz także wówczas, gdy jest niezawinione przez pracownika. Jednak jednorazowe drobne uchybienie obowiązkom z reguły nie uzasadnia wypowiedzenia;

7) zastosowanie wobec pracownika kary porządkowej za określone przewinienie nie stoi na przeszkodzie uznaniu, że uzasadnia ono wypowiedzenie umowy o pracę, jeżeli waga tego przewinienia jest znaczna;

8) przyczynę wypowiedzenia mogą stanowić również okoliczności niezależne od pracownika, jeżeli przemawia za tym uzasadniony interes pracodawcy;

9) zmniejszenie stanu zatrudnienia w zakładzie pracy stanowi uzasadnioną przyczynę wypowiedzenia. Organ rozpatrujący spory pracownicze nie jest powołany do badania zasadności i celowości zmniejszenia stanu zatrudnienia. Jednak okoliczności przemawiające za ochroną pracownika mogą powodować, że wypowiedzenie umowy konkretnemu pracownikowi jest nieuzasadnione lub sprzeczne z zasadami współżycia społecznego;

10) zasadność wypowiedzenia nie jest uzależniona od uprzedniego zaoferowania pracownikowi przez zakład pracy innej odpowiedniej pracy, którą dysponuje zakład pracy, chyba że obowiązek taki wynika z przepisu; 
11) okoliczności uzasadniające wypowiedzenie powinny istnieć przed zawiadomieniem właściwego organu związku zawodowego o zamiarze wypowiedzenia (art. $38 \S 1 \mathrm{KP}$ ), a gdy współdziałanie ze związkiem zawodowym nie jest wymagane lub możliwe najpóźniej w dacie złożenia pracownikowi oświadczenia woli o wypowiedzeniu;

12) wypowiedzenie nie jest ograniczone terminem od ujawnienia przyczyny uzasadniającej rozwiązanie umowy. Jeżeli jednak okoliczność uzasadniająca wypowiedzenie na skutek upływu czasu stała się nieaktualna ze względu na cel wypowiedzenia, może być ono uznane za nieuzasadnione" (Rycak 2018: 179-180).

Mimo że obecnie już te wytyczne mają charakter nieobowiązujących ze względu na uchylenie podstawy prawnej ich wydania, nadal stanowią one punkt wyjścia dla współczesnych sędziów przy analizie zasadności wypowiedzenia umowy o pracę przez pracodawcę i są bardzo często powoływane w orzecznictwie sądowym (Mitrus 2018: 87).

Jak zauważono wyżej, Sąd Najwyższy w swoich wyrokach nie tylko formułuje ogólne zasady uznania wypowiedzenia umowy o pracę przez pracodawcę za zasadne w świetle art. $45 \S 1 \mathrm{KP}$, lecz również wypowiada się w konkretnych sprawach.

Tak w wyroku z dnia 5 września 1997 r. (I PK 223/97) Sąd Najwyższy stwierdził, że „pracownik podejmujący działalność gospodarczą kolidującą z jego rolą jako strony stosunku pracy powinien przejawiać szczególną dbałość, by w praktyce nie prowadziło to do zagrożenia dobrego imienia pracodawcy; jego zachowanie nie spełniające tego wymagania stanowi przyczynę uzasadniającą wypowiedzenie mu umowy o pracę niezależnie od tego czy można mu przypisać winę".

Przyczyną, która może uzasadnić wypowiedzenie umowy pracownikowi, może stać się utrata zaufania do pracownika. Utrata zaufania do pracownika może uzasadniać wypowiedzenie umowy o pracę, mimo że jego zachowanie nie nosi cech zawinienia, jeżeli w konkretnych okolicznościach jest usprawiedliwiona, w tym znaczeniu, że od pracodawcy nie można wymagać, by nadal darzył pracownika niezbędnym zaufaniem (wyrok SN z 07.09.1999, I PKN 257/99).

Kolejną przyczyną uzasadniającą wypowiedzenie umowy o pracę mogą być względy racjonalizacji zatrudnienia, zmierzającej do obniżenia kosztów działalności przedsiębiorcy (wyrok SN z 16.06.1999, I PKN 106/99).

W przypadku przeciwwskazania lekarskiego do pracy na zajmowanym stanowisku pracodawca również może wypowiedzieć umowę pracownikowi, nie narażając się na zastosowanie sankcji z art. 45 KP (wyrok SN z 23.01.1998, I PKN 49/97).

W świetle judykatury za przyczyny uzasadniające wypowiedzenie uważa się takie okoliczności, jak:

1) nieprzewidziana, długotrwała i powtarzająca się nieobecność w pracy, wymagająca podejmowania przez pracodawcę działań natury organizacyjnej (ewentualnie wyznaczenia zastępstw) i pociągająca za sobą wydatki na zatrudnienie w godzinach nadliczbowych lub innych osób na podstawie umów zlecenia, chociażby była niezawiniona i formalnie usprawiedliwiona (wyrok SN z 04.12.1997, I PKN 422/97); 
2) osiągnięcie przez kobietę wieku emerytalnego oraz uzyskanie prawa do emerytury (wyrok SN z 21.04.1999, I PKN 31/99);

3) odwołanie pracownika ze stanowiska prezesa zarządu spółki akcyjnej, jeżeli zawarcie umowy o pracę wiązało się bezpośrednio z powołaniem go na tę funkcję (wyrok SN z 25.11.1997, I PKN 388/97);

4) naruszenie przez pracownika w zakładzie pracy zasad współżycia społecznego, np. zeznania nieprawdy co do faktów powszechnie znanych załodze w toczącym się postępowaniu powypadkowym (wyrok SN z 12.01.1998, I PKN 458/97);

5) brak kwalifikacji do wykonywania nowych zadań, utrata zdrowia, niezawiniona utrata uprawnień koniecznych do wykonywania zawodu, niedbałe wykonywanie pracy, cofnięcie dostępu do wiadomości stanowiących tajemnicę państwową (wyrok SN z 11.01.1991, I PRN 55/90);

6) odmowa przyjęcia i podpisania zakresu czynności ustalonego zgodnie z umową o pracę (wyrok SN z 03.04.1997, I PKN 77/97);

7) odmowa przedłużenia pełnomocnictwa do dokonywania w imieniu i na rzecz pracodawcy wszelkich określonych w regulaminie organizacyjnym czynności, wynikających z zarządu jego terenową jednostką (wyrok SN z 26.08.1999, I PKN 182/99).

\section{Stosunek pomiędzy klauzulą „wypowiedzenie nieuzasadnione"}

a klauzulami „zasad współżycia społecznego"

oraz „społeczno-gospodarczego przeznaczenia prawa"

Przy rozpatrzeniu problemu zasadności wypowiedzenia wcześniej lub później powstaje pytanie o relacje pomiędzy klauzulą „wypowiedzenia nieuzasadnionego” a klauzulą „zasad współżycia społecznego" oraz klauzulą „społeczno-gospodarczego przeznaczenia prawa", zawartymi w art. $8 \mathrm{KP}$.

Obecnie w doktrynie funkcjonują dwa poglądy dotyczące stosunków pomiędzy klauzulą wypowiedzenia nieuzasadnionego a klauzulą zasad współżycia społecznego.

Zgodnie z pierwszym z tych nurtów przyjmuje się, iż wypowiedzenie nieuzasadnione jednocześnie będzie odpowiadało sytuacji, przy której pracodawca będzie naruszał zasady współżycia społecznego (Rycak 2018: 177). Przyjmując takie stanowisko, sąd pracy przy stwierdzeniu, iż wypowiedzenie umowy o pracę było uzasadnione, nie musi już dalej oceniać, czy jest ono zgodne z zasadami współżycia społecznego, czy jednak nie.

Zwolennicy drugiego podejścia uważają, iż wypowiedzenie nieuzasadnione nie jest jednocześnie niezgodne z zasadami współżycia społecznego (Rycak 2018: 177). Tak samo nieprawidłowe będzie i stwierdzenie odwrotne, według którego wypowiedzenie uzasadnione nie może być sprzeczne z klauzulą zasad współżycia społecznego.

W stosunku do relacji pomiędzy klauzulami „nieuzasadnionego wypowiedzenia” oraz „społeczno-gospodarczego przeznaczenia prawa” sprzeczność poglądów też istnieje. Tak w doktrynie z jednej strony popiera się pogląd, iż klauzula „nieuzasadnionego wypowiedzenia” pochłania klauzulę „społeczno-gospodarczego przeznaczenia 
prawa", w związku z czym nieuzasadnione wypowiedzenie będzie jednocześnie godziło w społeczno-gospodarcze przeznaczenia prawa, zaś z drugiej uważa się, że nie jest dopuszczalna teza o wzajemnych podporządkowaniach klauzuli generalnych (Rycak 2018: 178).

Na tle takiej niezgodności poglądów doktryny podobne sprzeczności istnieją i w orzecznictwie. Nie zawsze w przypadku stwierdzenia przez sąd zasadności wypowiedzenia orzeka on o zgodności tego wypowiedzenia z zasadami współżycia społecznego. I tak w wyroku z dnia 19 grudnia 1996 r. (I PKN 46/96) Sąd Najwyższy zajął stanowisko, iż w razie zmniejszenia zatrudnienia wybór zwalnianego pracownika może być sprzeczny z zasadami współżycia społecznego wtedy, gdy jego sytuacja osobista jest znacznie gorsza niż pozostałych pracowników. Na przykładzie tego orzeczenia jest widoczne, iż klauzula "wypowiedzenia uzasadnionego" może mieć inny zakres przedmiotowy niż klauzula „zasad współżycia społecznego". Orzeczenie wydane trzy lata później potwierdza to podejście i zawiera tezę, iż wypowiedzenie umowy o pracę długoletniemu pracownikowi, który utracił zdrowie w związku przyczynowym z rażąco naruszającymi zasady bezpieczeństwa i higieny pracy warunkami wykonywania zatrudnienia, może być sprzeczne z zasadami współżycia społecznego (wyrok SN z 28.10.1998, I PKN 398/98).

\section{Zasadność wypowiedzenia umowy o pracę na tle unijnym (Mitrus 2018: 42-44)}

Traktaty założycielskie Unii Europejskiej w swej treści nie zawierają postanowień wprowadzających wprost zakaz wypowiedzenia umowy o pracę zawartej na czas nieokreślony bez podania przyczyn jego uzasadniających. Natomiast art. 153 ust. 1 Traktatu o funkcjonowaniu Unii Europejskiej (Dz. U. z 2004 r. Nr 90, poz. 864) zawiera postanowienie, iż Unia wspiera i uzupełnia działania państw członkowskich w dziedzinie ochrona pracowników w przypadku wypowiedzenia umowy o pracę. W tym celu Parlament Europejski i Rada mogą przyjąć środki w celu zachęcania do współpracy między państwami członkowskimi w drodze inicjatyw zmierzających do pogłębiania wiedzy, rozwijania wymiany informacji i najlepszych praktyk, wspierania podejść nowatorskich oraz oceny doświadczeń, z wyłączeniem jakiejkolwiek harmonizacji przepisów ustawowych i wykonawczych państw członkowskich. Na poparcie tej tezy w Karcie praw podstawowych Unii Europejskiej (Dz. Urz. UE C 83 2010) został dodany art. 30. Według tego przepisu każdy pracownik ma prawo do ochrony w przypadku nieuzasadnionego zwolnienia z pracy, zgodnie z prawem Unii oraz ustawodawstwami i praktykami krajowymi.

Obecnie w prawie wtórnym Unii Europejskiej brak jest dyrektyw wprowadzających jakiekolwiek uregulowania w zakresie wypowiedzenia umowy o pracę przez pracodawcę z przyczyn leżących po stronie pracownika. Czasami w niektórych aktach prawnych Unii Europejskiej można spotkać się z pojedynczymi przepisami pośrednio odnoszącymi się do tego przedmiotu. 
Za przykład takich odrębnych uregulowań może posłużyć art. 4 Dyrektywy 2001/23/ WE w sprawie ochrony praw pracowniczych w przypadku przejęcia przedsiębiorstwa lub zakładu (Dz. U. L 82 2001: 16-20), zgodnie z którym przejęcie przedsiębiorstwa, zakładu lub części przedsiębiorstwa lub zakładu nie stanowi samo w sobie podstawy do zwolnienia, czy to przez zbywającego, czy przejmującego.

Dyrektywa Rady 2000/78/WE z dnia 27 listopada 2000 r. (Dz. U. L 303 2000) z kolei ustanawia ogólne ramy służące zagwarantowaniu równego traktowania wszystkich osób w Unii Europejskiej w miejscu pracy, bez względu na ich religię lub przekonania, niepełnosprawność, wiek czy orientację seksualną.

\section{Zakończenie}

Problem zasadności wypowiedzenia umowy o pracę zawartej na czas nieokreślony jest dosyć obszerny i budzący zainteresowanie nauki prawa pracy od dawna. Zainteresowanie to przede wszystkim jest związane z przynależnością tego zagadnienia do instytucji ochrony trwałości stosunku pracy.

Obecnie w systemie polskiego prawa pracy funkcjonuje ogólny zakaz rozwiązania przez pracodawcę umowy o pracę za wypowiedzeniem bez uzasadnionych przyczyn. Za wypowiedzenie nieuzasadnione w świetle orzecznictwa i doktryny będzie się uważało wypowiedzenie oparte na przyczynach sprzecznych z ogólnymi zasadami wykładni klauzuli generalnej z art. 45 § $1 \mathrm{KP}$ oraz wypowiedzenie oparte na przyczynach niedozwolonych wymienionych wprost w Kodeksie pracy w art. $23^{1} \S 6$, art. 679 , art. $18^{3 \mathrm{e}} \S 1 \mathrm{i}$ art. $18^{3 \mathrm{e}} \S 2 \mathrm{KP}$.

Za ogólne zasady, na których powinna opierać się wykładnia pojęcia „wypowiedzenie nieuzasadnione", obecnie uznaje się takie stwierdzenia, jak:

1) przyczyna wypowiedzenia umowy o pracę musi być konkretna i rzeczywista;

2) przyczyna ta nie musi jednak mieć szczególnej wagi czy nadzwyczajnej doniosłości;

3) wypowiedzenie jest zwykłym sposobem rozwiązania bezterminowego stosunku pracy;

4) brak oczekiwanej przez pracodawcę dbałości, staranności i uwagi w wykonywaniu obowiązków pracowniczych uzasadnia wypowiedzenie pracownikowi umowy o pracę;

5) pracodawca w sposób zasadny wypowiada umowę o pracę pracownikowi samodzielnie organizującemu wykonywanie swoich obowiązków pracowniczych, jeżeli pracownik ten nie osiąga wyników porównywalnych z innymi pracownikami, obojętne jest czy spowodowane to zostało niestarannym wykonywaniem obowiązków pracownika czy przyczynami obiektywnymi, leżącymi po stronie pracownika;

6) przy ocenie zasadności wypowiedzenia umowy o pracę należy uwzględnić słuszny interes zakładu pracy;

7) przy wypowiedzeniu umowy o pracę nie musi być stwierdzona wina pracownika, lecz tylko musi być uzasadnione rozwiązanie stosunku pracy w takim trybie; 
8) przyczyny wypowiedzenia nie muszą charakteryzować się znaczną wagą ani powodować szkód po stronie pracodawcy;

9) zasadność wypowiedzenia umowy o pracę na czas nieokreślony należy oceniać z uwzględnieniem łącznie wszystkich przyczyn wskazanych przez pracodawcę.

Należy podkreślić, że przy ocenie zasadności wypowiedzenia w każdym konkretnym stanie faktycznym warto mieć na uwadze orzecznictwo, w którym Sąd Najwyższy wypowiada się odnośnie do poszczególnych przypadków, bowiem „nie jest możliwe wyczerpujące skatalogowanie przyczyn wypowiedzenia umowy o pracę ani ustalenie sztywnych kryteriów oceny wypowiedzenia, a tylko wskazanie głównych kierunków" (uchwała SN z 27.06.1985).

\section{Bibliografia}

\section{Literatura:}

Florek L., 2011, Dział drugi. Stosunek pracy. Rozdział II. Umowa o pracę [w:] L. Florek (red.), Kodeks Pracy. Komentarz, Warszawa.

Mitrus L., 2018, Wypowiedzenie umowy o pracę z przyczyn dotyczących pracownika, Warszawa.

Rycak A., 2018, Rozdział VI. Ustanie umownego stosunku pracy [w:] J. Stelina (red.), Prawo pracy, Warszawa.

\section{Akty prawne:}

Ustawa z dnia 23 kwietnia 1964 r. - Kodeks cywilny, t.j. Dz. U. z 2018 r., poz. 1025 ze zm.

Ustawa z dnia 21 listopada 1967 r. o powszechnym obowiązku obrony Rzeczypospolitej Polskiej, t.j. Dz. U. z 2019 r. poz. 55 ze zm.

Ustawa z dnia 26 czerwca 1974 r. - Kodeks pracy, t.j. Dz. U. z 2018 r., poz. 907 ze zm.

Konwencja Nr 158 Międzynarodowej Organizacji Pracy dotycząca rozwiązania stosunku pracy z inicjatywy pracodawcy z dnia 23 listopada 1985 r., http://www.mop.pl/doc/html/konwencje/k158. html (dostęp: 11.03.2019).

Zrewidowana Europejska Karta Społeczna z dnia 3 maja 1996 r., http://www.nzzk.nw.pl/pdf/eu_ karta_spol.pdf, (dostęp 11.03.2019 r.)

Dyrektywa Rady 2000/78/WE z dnia 27 listopada 2000 r. ustanawiająca ogólne warunki ramowe równego traktowania w zakresie zatrudnienia i pracy, Dz. U. L 303 z 2.12.2000 r.

Dyrektywa Rady 2001/23/WE z dnia 12 marca 2001 r. w sprawie zbliżania ustawodawstw Państw Członkowskich odnoszących się do ochrony praw pracowniczych w przypadku przejęcia przedsiębiorstw, zakładów lub części przedsiębiorstw lub zakładów, Dz. U. L 82 z 22.3.2001 r.

Ustawa z dnia 13 marca 2003 r. o szczególnych zasadach rozwiązywania z pracownikami stosunków pracy z przyczyn niedotyczących pracowników, t.j. Dz. U. z 2018 r., poz. 1969.

Traktat o funkcjonowaniu Unii Europejskiej - tekst skonsolidowany uwzględniający zmiany wprowadzone Traktatem z Lizbony, Dz. U. z 2004 r. Nr 90, poz. 864. 


\section{Orzecznictwo:}

Wyrok Sądu Najwyższego z dnia 4 kwietnia 1979 r., I PKN 32/79, LEX 14491.

Uchwała pełnego składu Izby Pracy i Ubezpieczeń Społecznych Sądu Najwyższego z dnia 27 czerwca 1985 r. w sprawie wytycznych dotyczących wykładni art. 45 Kodeksu pracy i praktyki sądowej stosowania tego przepisu w zakresie zasadności wypowiedzenia umowy o pracę zawartej na czas nie określony z dnia 27.06.1985 r., M. P. z 1985 r. Nr 24, poz. 192.

Wyrok Sądu Najwyższego z dnia 11 stycznia 1991 r., I PRN 55/90, Rejent z 1991 r., nr 9, str. 162.

Wyrok Sądu Najwyższego z dnia 2 października 1996 r., I PKN 69/96, OSNAPiUS z 1998 r., nr 10, poz. 163. Wyrok Sądu Najwyższego z dnia 19 grudnia 1996 r., I PKN 46/96, OSN z 1997 r., nr 15, poz. 273.

Wyrok Sądu Najwyższego z dnia 3 kwietnia 1997 r., I PKN 77/97, OSN z 1998 r., nr 3, poz. 75.

Wyrok Sądu Najwyższego z dnia 28 kwietnia 1997 r., I PKN 1 18/97, OSNAPiUS z 1998 r., nr 7, poz. 206. Wyrok Sądu Najwyższego z dnia 5 września 1997 r., I PK 223/97, OSNAPiUS z 1998 r., nr 11, poz. 327. Wyrok Sądu Najwyższego z dnia 25 listopada 1997 r., I PKN 388/97, OSN z 1998 r., nr 18, poz. 540. Wyrok Sądu Najwyższego z dnia 4 grudnia 1997 r., I PKN 422/97, OSN z 1998 r., nr 20, poz. 600. Wyrok Sądu Najwyższego z dnia 12 stycznia 1998 r., I PKN 458/97, OSN z 1998 r., nr 22, poz. 655. Wyrok Sądu Najwyższego z dnia 23 stycznia 1998 r., I PKN 49/97, OSN z 1999 r., nr 1, poz. 10. Wyrok Sądu Najwyższego z dnia 28 października 1998 r., I PKN 398/98, OSNAPiUS 1999 r., nr 23, poz. 751. Wyrok Sądu Najwyższego z dnia 10 listopada 1998 r., I PKN 434/98, OSNAPiUS z 1999 r., nr 21, poz. 688. Wyrok Sądu Najwyższego z dnia 17 listopada 1998 r., I PKN 331/98 , OSNP z 1999 r., nr 21, poz. 690. Wyrok Sądu Najwyższego z dnia 24 marca 1999 r., I PKN 637/98, OSNAPiUS z 2000 r., nr 10, poz. 386. Wyrok Sądu Najwyższego z dnia 15 kwietnia 1999 r., I PKN 9/99, OSNAPiUS z 2000 r., nr 12, poz. 464. Wyrok Sądu Najwyższego z dnia 21 kwietnia 1999 r., I PKN 31/99, OSNAP z 2000 r., nr 13, poz. 505 Wyrok Sądu Najwyższego z dnia 16 czerwca 1999 r., I PKN 106/99, OSN z 2000 r., nr 16, poz. 619. Wyrok Sądu Najwyższego z dnia 26 sierpnia 1999 r., I PKN 182/99, OSN z 2000 r., nr 23, poz. 858. Wyrok Sądu Najwyższego z dnia 7 września 1999 r., I PKN 257/99 , OSNAPiUS z 2001 r., nr 1, poz. 14. Wyrok Sądu Najwyższego z dnia 13 listopada 1999 r., I PKN 304/99, OSNAPiUS z 2001 r., nr 4, poz. 118. Wyrok Sądu Najwyższego z dnia 23 listopada 2000 r., I PKN 117/00, OSNAPiUS z 2002 r., nr 13, poz. 304. Wyrok Sądu Najwyższego z dnia 18 kwietnia 2001 r., I PKN 370/00, OSNP z 2003 r., nr 3, poz. 65. Uchwała Sądu Najwyższego z dnia 2 października 2002 r., III PZP 17/2002 , Biul. SN z 2002 r. nr 10, s. 4. Wyrok Sądu Najwyższego z dnia 8 stycznia 2007 r., I PK 187/06, OSNP z 2008 r., nr 3-4, poz. 35.

\section{Biogram}

Eugenia Tereszczenko - studentka Wydziału Prawa i Administracji Uniwersytetu Gdańskiego. Zainteresowania: prawo pracy, prawo prywatne międzynarodowe. 